\title{
The influence of competition and species mixture on plantation-grown white spruce: Growth and foliar nutrient response after 20 years
}

\author{
by Breanne A. Neufeld ${ }^{1}$, Dave M. Morris ${ }^{2}$, Nancy Luckai ${ }^{1{ }^{*}}$, Douglas E.B. Reid ${ }^{2}$, F. Wayne Bell ${ }^{3}$, Chander Shahi', \\ W. Lense Meyer ${ }^{1}$ and Shailendra Adhikary ${ }^{1}$
}

\begin{abstract}
A 20-year-old experimental white spruce plantation was used to identify key stand (neighbourhood competition) and soil (physical and chemical properties) factors influencing spruce growth (Periodic Basal Area Increment) and foliar nutrients. Total and species-specific competition was estimated using Hegyis distance-dependent index for 39 individual spruce trees. Twelve trees, covering the range of total HCI (2 to 8$)$ and aspen competition ( $0 \%$ to $>75 \%)$, were selected for repeated (May through October) foliar sampling. Spruce PBAI declined approximately $10 \%$ for each additional unit of total HCI; species did not significantly affect this decline. Increasing aspen presence significantly influenced spruce foliar $\mathrm{N}(1.17 \%$ to $1.31 \%), \mathrm{P}$ $(0.15 \%$ to $0.23 \%)$, and $\mathrm{K}(0.68 \%$ to $0.88 \%)$, but led to declines in $\mathrm{Ca}(0.81 \%$ to $0.48 \%)$. Multiple linear regression indicated that soil carbon (partial $r^{2}=0.386$ ) and available soil moisture (partial $r^{2}=0.131$ ) together explained more of the variation in spruce growth than did competition factors alone (partial $r^{2}=0.251$ ). The results suggest that, at this stage of stand development, precommercial thinning operations should focus on density control and inter-tree spacing, while retaining an aspen component resulting in well-spaced, free-growing mixed stands of white spruce and aspen.
\end{abstract}

Keywords: Fallingsnow Ecosystem Project, Hegyi’s Competition Index, trembling aspen, seasonal pattern in foliar nutrients, spruce-aspen mixedwoods

\begin{abstract}
RÉSUMÉ
Une plantation expérimentale dépinette blanche âgée de 20 ans a été utilisée pour identifier les principaux facteurs de peuplement (compétition avoisinante) et de sol (propriétés physiques et chimiques) qui influencent la croissance de lépinette (accroissement périodique de la surface terrière) et les éléments nutritifs du feuillage. La compétition globale et spécifique a été estimée au moyen de lindex de distance de Hegyi pour 39 épinettes. Douze arbres, représentant lensemble des classes de hauteur (de 2 à 8 ) et de la compétition par le tremble (de $0 \%$ à $>75 \%$ ), ont été choisis à des fins déchantillonnages foliaires répétés (de mai à octobre). Laccroissement périodique de la surface terrière des épinettes a diminué de près de $10 \%$ pour chacune des classes de hauteur successives; cette réduction nétait pas liée à lessence compétitrice. La présence croissante du tremble a amélioré significativement lazote foliaire de lépinette (de $1,17 \%$ à $1,31 \%$ ), son phosphore (de $0,15 \%$ à $0,23 \%$ ) et son potassium (de $0,68 \%$ à $0,88 \%$ ), mais a provoqué une diminution du niveau de calcium (de $0,81 \%$ à $0,48 \%$ ). Une régression linéaire multiple a permis de constater que le carbone du sol $\left(r^{2}\right.$ partiel $\left.=0,386\right)$ et l'humidité disponible dans le sol $\left(r^{2}\right.$ partiel $\left.=0,131\right)$ contribuaient davantage à expliquer la variation de la croissance de lépinette que ne lont fait les facteurs de compétition pris dans leur ensemble $\left(r^{2}\right.$ partiel $\left.=0,251\right)$. Les résultats laissent croire quà ce stade du développement du peuplement, il faudrait orienter les opérations déclaircie précommerciale vers le contrôle de la densité et de lespacement entre les arbres tout en conservant certaines tiges de tremble, de façon à obtenir un peuplement mixte dépinette blanche et de tremble bien dégagé et libre de croitre.
\end{abstract}

Mots clés : Projet écosystémique de Fallingsnow, Index de compétition de Hegyi, peuplier faux-tremble, concentration saisonnière des éléments nutritifs dans le feuillage, peuplements mixtes épinette-tremble

\section{Introduction}

The boreal mixedwood forest comprises over half of Ontario's productive forest landbase (McClain 1981) and contributes substantially to Ontario's annual wood supply (Bell et al. 2000). As a result, these productive stand types have been identified as prime sites for intensified management (Bell et al. 2000). These management approaches, however, largely focus on maximizing conifer production through the control of competing vegetation, which in the boreal often involves hardwood shrubs or trees (Pitt et al. 2010). In addition to the many ecological benefits such as enhanced structural and biological diversity, habitat availability and resistance to pests (Kelty 1992, 2006), mixedwood conditions may also result in greater overall productivity (Man and Greenway 2004, Lieffers et al. 2007, Cortini et al. 2012). While this previous work suggests the potential for a beneficial interaction between tree species in boreal mixedwoods, the mechanisms whereby these interactions influence growth at the individual tree level remain poorly understood.

The extent to which a tree can influence its neighbours by modifying localized growth-limiting resources depends on the species in question, as well as the relative size and distance away of those neighbours (Gray and He 2009). White spruce

\footnotetext{
${ }^{1}$ Faculty of Natural Resources Management, Lakehead University, 955 Oliver Road, Thunder Bay, Ontario P7B 5E1.

${ }^{2}$ Centre for Northern Forest Ecosystem Research, Ontario Ministry of Natural Resources, 955 Oliver Road, Thunder Bay, Ontario P7B 5E1.

${ }^{3}$ Ontario Forest Research Institute, Ontario Ministry of Natural Resources, 1235 Queen St. E., Sault Ste. Marie, Ontario P6A 2 E5.

*Corresponding author. E-mail: nluckai@lakeheadu.ca
} 
(Picea glauca [Moench.] Voss) is a moderately shade-tolerant boreal conifer that tends to dominate in mid- to late successional stages; trembling aspen (Populus tremuloides Michx.) is a fast-growing, shade-intolerant, pioneer hardwood (Nienstaedt and Zasada 1990, Perala 1990). Although it has been commonly thought that an aspen canopy reduces survival and growth of understory white spruce, aspen overstories appear to reduce the negative impacts of weather extremes (e.g., frost damage, Man and Lieffers 1997), pests (MacKinnon and MacLean 2003) and other stressors on younger, smaller white spruce (Comeau 1996, Groot and Carlson 1996, Pritchard and Comeau 2004). The combination of white spruce's lower photosynthetic compensation point (Man and Lieffers 1997, Coates and Burton 1999) and aspen's low leaf area, may result in aspen having less shading effect on spruce than would other spruce trees, with results suggesting aspen presence does not greatly decrease spruce photosynthetic rates (Pritchard and Comeau 2004). Understory white spruce may also be able to take advantage of aspen's leafoff period in the spring and fall (Constabel and Lieffers 1996, Voicu and Comeau 2006); understory spruce have higher mesophyll conductance in both of these seasons, and higher stomatal conductance in the fall relative to open-grown seedlings, allowing for an extended growing season (Man and Lieffers 1997).

From a nutritional aspect, it has also been proposed that the presence of aspen litter may improve forest floor and soil conditions by increasing decomposition rates, reducing acidification and increasing nutrient availability (Wang et al. 1995, Man and Lieffers 1999). This increase in soil nutrient levels has, in turn, resulted in higher nutritional levels in spruce foliage (Ballard and Carter 1986, Wang and Klinka 1997, McAlister and Timmer 1998, Boivin et al. 2004). In addition, if vertical and horizontal root stratification occurs when spruce and aspen are grown in mixtures (Lawrence et al. 2012), both species may access more space for root growth, thus improving their ability to capture soil resources (Man and Lieffers 1999) and/or leading to enhanced nutrient uptake during the growing season. Through the mechanisms of facilitation (e.g., higher quality foliar litter) and/or complementarity (e.g., foliar and rooting stratification), the presence of aspen may affect the amount and availability of soil nutrients, thus benefiting white spruce.

To date, studies examining the question of improved productivity in aspen/white spruce mixtures have provided mixed results. Many of these studies dealt with very young spruce plantations ( $<10$ years of age, e.g., Man and Lieffers 1997, Bokalo et al. 2007, Pitt et al. 2010), often with differently aged cohorts of spruce and aspen (e.g., Gradowski et al. 2008, MacPherson et al. 2001, Lieffers et al. 1996), or used modeling scenarios (e.g., Bell et al. 2011, Cortini et al. 2012) to examine productivity projections. In most cases, competition effects are often examined at the plot or stand level. While distance-independent indices (e.g., relative yield, stand density and basal area) may be adequate for estimating competitive effects in spatially regular, pure, evenaged stands (Lorimer 1983), distance-dependent indices take into account spatially explicit variation in the strength of competition among trees (Wagner and Radosevich 1998). Indices like Hegyis Competition Index (HCI, Hegyi 1974) give greater weight to relatively larger and closer neighbours compared to those that are relatively smaller or further away. This is based on the expectation that a larger and closer competitor will have a greater influence on local growth resources than a smaller and/ or more distant tree. Differences in species' competitiveness are, however, not accounted for by HCI. Nevertheless, this index has proven useful as a measure of the competitive effects of neighboring trees on individual tree growth (Clinton et al. 1997, Bristow et al. 2006).

In this study, we utilized a 20-year-old experimental white spruce plantation to examine the influence of both trembling aspen and white spruce competition on individual spruce tree growth and foliar nutrition. The overall objective of the study was to identify the key stand, soil, and site factors influencing 20 -year-old plantation white spruce growth and foliar nutrient levels. Specifically, we sought to determine i) does aspen and spruce competition differ in terms of their influence on spruce tree growth?, and ii) does the presence of aspen influence soil nutrient levels and spruce foliar nutrient status?

\section{Materials and Methods \\ Study site and data collection}

This study was conducted within the Fallingsnow Ecosystem Project (FEP), situated at $89^{\circ} 50^{\prime} \mathrm{W}$ and $48^{\circ} 10^{\prime} \mathrm{N}$, approximately $60 \mathrm{~km} \mathrm{SW}$ of Thunder Bay in northwestern Ontario. The FEP is located in the transition zone between the boreal and Great lakes - St. Lawrence forests (Rowe 1972) at an elevation of $400 \mathrm{~m}$. Mean annual precipitation is $845 \mathrm{~mm}$, with a mean annual temperature of $2.1^{\circ} \mathrm{C}$. The area is characterized by productive, fine-textured soils that are predominantly imperfectly drained, silt loams to silty clay loams (Simpson et al. 1997). The soil profile has well-developed $\mathrm{Ah}(5 \mathrm{~cm}$ to $10 \mathrm{~cm})$ and Bt horizons, classified as Gleyed Dark Gray Luvisols (Soil Classification Working Group 1998). Before harvest in 1986-1988, mature aspen-dominated mixedwoods were present. The area was planted with white spruce at 1700 stems/ha in 1989-90 (Bell et al. 1997). In 1993, vegetation management treatments (mechanical and herbicide) were applied leading to a range in densities and proportions of even-aged aspen and spruce (Pitt and Bell 2005). Previously established, stem-mapped plots were used to generate a population of potential subject spruce trees each at the centre of a 3-m radius plot; we refer to these as Tree-Centred Plots (TCPs). After discarding trees that were suppressed (i.e., $\mathrm{DBH}<4 \mathrm{~cm}$ ), located on the edges of unusually large openings, experiencing competition from species or individuals other than young aspen or spruce, or had significant deformities (e.g., double stems), approximately 350 spruce subject trees remained.

For each tree, the amount and source of competition from neighbouring spruce and aspen trees was estimated within each TCP using Hegyis distance-dependent competition index (HCI). We chose a 3-m radius for the TCPs, which was double the average spruce and aspen crown radius and large enough to include several competitor trees in the immediate vicinity of the subject tree. The percentage of total HCI in each TCP attributable to aspen or spruce was calculated. Each subject tree was then assigned to one of four competition categories according to the percentage of competition provided by aspen trees in the TCP (aspen0: $0 \%-12.5 \%$, aspen $25: 12.5 \%-37.5 \%$, aspen 50 : $37.6 \%-62.5 \%$, and aspen $75:>62.6 \%$ ).

\section{Spruce growth response using basal area increment}

Twelve trees were randomly selected from each competition category to give a pool of 48 trees. After field reconnaissance, we eliminated nine trees due to forked tops, evidence of insect damage, or those that died since the previous assessment leaving 39 spruce trees with their associated TCPs. Based on basal cores taken at approximately $30 \mathrm{~cm}$, subject trees were confirmed to 
be within the range of ages associated with the time of planting. Ages recorded were generally in the 21- to 22-year range, but values as low as 19 years were observed, likely reflecting some error in the measurement of age at stump height and/or planting shock resulting in slow growth in the first years after planting. Potential subject trees with ages less than this were typically smaller, representing natural ingress after the time of initial establishment and application of vegetation control treatments, and were thus not used. The resulting dataset represents a broad range in stand density ( 1415 to 6720 stems/ha) and species composition (pure spruce - aspen0 category to over $80 \%$ aspen - aspen 75 category) (Table 1 ).

Two cores at breast height (1.3 m, approximately perpendicular to one another) were collected from each subject tree in April/May 2010 and stored in plastic straws, as described by Cole (1977). In preparation for analysis, the cores were glued into wooden blocks with grooves and sanded flush with the wooden block. The sanded cores were scanned, measured and analysed using WinDENDRO software and corrected to actual DBH measurements as described by Clark et al. (2007). Basal area increment was calculated for the previous five years (20052009) and averaged on a per year basis (PBAI measured in $\mathrm{cm}^{2}$ per year). PBAI was selected as the response variable as it has been shown to be highly sensitive to density and competition levels compared to other variables such as height growth (Morris et al. 1990, Morris and MacDonald 1991). To ensure that there were no residual effects of the vegetation control treatments (i.e., manual versus herbicide treatments) conducted in 1993 on growth, we compared the regression parameters (i.e., slope and y-intercepts) of PBAI against total HCI for the two vegetation control treatments. The slope of the regression of basal area increment against total HCI did not differ between treatment groups $(P=0.68)$; we therefore pooled the data ( $\mathrm{Zar}$ 1999). Although the intercepts did differ, these values fell well outside the range of competition being considered in this paper.

\section{Soil physical and chemical attributes}

In 2008, as part of the ongoing research at the FEP, soil pits were located in a representative area and excavated, to a maximum depth of $40 \mathrm{~cm}$, in each of the stem-mapped plots. Soil horizons were delineated, horizon depths measured, and individual horizon samples were collected and analyzed for physical and chemical attributes. For this study, we used data from the organic (L, F, H) and the top mineral (Ah horizon, ranging in depth from $4 \mathrm{~cm}$ to $24 \mathrm{~cm}$ ) horizon from each plot where subject trees were located. Soil samples were then air-dried and passed through a $2 \mathrm{~mm}$ sieve. Soil physical attributes of interest were fine fraction bulk density (core method; Kalra and Maynard 1991), volumetric coarse fragment content, and available soil moisture (determined as the moisture content difference between measured field capacity and permanent wilting point; Kalra and Maynard 1991). Chemical analyses included soil $\mathrm{pH}$, extractable $\mathrm{P}$ (Bray method), $\mathrm{Mg}, \mathrm{K}, \mathrm{Ca}$ (ammonium replacement method), $\mathrm{NO}_{3}, \mathrm{NH}_{4}$ ( $\mathrm{KCl}$ method) (Kalra and Maynard 1991), dissolved organic carbon (AutoAnalyzer II, Industrial Method NO. 455-76W/A), total soluble nitrogen (AutoAnalyzer II, Industrial Method No. 759-841) and total N (automated combustion method with LECO-CNS; Horneck and Miller 1998). Standard QA/QC procedures were followed (i.e., duplicates and quality controls were included).

\section{Spruce foliar nutrition}

To investigate the link between species mixture, site and foliar nutrient status, we selected a sub-set of 12 spruce trees for intensive analyses. Three subject trees were randomly selected from each aspen competition category ensuring that we had representation across the range of aspen competition. ANOVA was used to verify that the average size of selected foliar sampling trees were similar $(\mathrm{DBH}=10.2, P=0.97 ; \mathrm{Ht}=6.9, P=0.94)$ and were experiencing similar plot density $(\mathrm{SPH}=3834, P=0.09)$, basal area $\left(\mathrm{BA}=23.3 \mathrm{~m}^{2} \cdot \mathrm{ha}^{-1}, P=0.22\right)$, and competition (total $\mathrm{HCI}=4.0, P=0.67)$ across the aspen competition categories.

We wished to track the accumulation of nutrients over the growing season to ensure that sampling of all spruce subject trees and comparisons of the mixture groups (see description of repeated measures ANOVA below) would be done at an appropriate time (i.e., after the point in time that nutrient concentration levels stabilized). Foliage collections were made every two weeks (late-May to mid-October) from three south-facing branches in the mid-crown from each of the 12 subject trees. One branchlet from each selected branch was removed using extended pruners; foliage was dried at $70^{\circ} \mathrm{C}$ for 24 hours and ground using a Wiley Mill (40 mesh screen). Foliar samples were analyzed for $\mathrm{N}$ (automated combustion method with LECO-CNS; Horneck and Miller 1998), and P, K, Ca, and Mg using a nitric-hydrochloric acid wet digestion adapted from Miller (1998), followed by ICP-AES (Munter and Grande 1981). Standard QA/QC procedures were followed (i.e., duplicates and quality controls were included). Sample weights were adjusted to reflect oven-dry weight $\left(105^{\circ} \mathrm{C}\right.$ for two hours).

\section{Statistical analysis}

The relationship between spruce PBAI and competition (spruce $\mathrm{HCI}$, aspen $\mathrm{HCI}$ and total $\mathrm{HCI}$ ) was examined using linear regression. Model fitting was accomplished using PROC REG in SAS, ver. 9.1 (SAS Institute Inc. 1987).

Table 1. Range, means and standard deviations for tree and stand level metrics in the Tree-Centred Plots [3-m radius]

\begin{tabular}{|c|c|c|c|c|c|c|c|c|c|c|}
\hline & \multicolumn{7}{|c|}{ Tree-Centred Plots } & \multicolumn{3}{|c|}{ Subject tree } \\
\hline & \multicolumn{4}{|c|}{ Hegyi's Competition Index } & \multicolumn{3}{|c|}{ Density (stems/ha) } & \multirow{2}{*}{$\begin{array}{c}\text { PBAI } \\
\left(\mathrm{cm}^{2} \text { per }\right. \\
\text { year })\end{array}$} & \multirow{2}{*}{$\begin{array}{l}\mathrm{DBH} \\
(\mathrm{cm})\end{array}$} & \multirow{2}{*}{$\begin{array}{r}\text { Heigh } \\
(\mathrm{m})\end{array}$} \\
\hline & $\begin{array}{l}\text { White } \\
\text { spruce }\end{array}$ & $\begin{array}{c}\text { Trembling } \\
\text { aspen }\end{array}$ & Total & \% Aspen & $\begin{array}{l}\text { White } \\
\text { spruce }\end{array}$ & $\begin{array}{c}\text { Trembling } \\
\text { aspen }\end{array}$ & Total & & & \\
\hline Min & 0.71 & 0.00 & 1.74 & 0.00 & 354 & 0 & 1415 & 3.90 & 7.40 & 5.00 \\
\hline Max & 5.28 & 6.49 & 7.97 & 0.81 & 3183 & 5305 & 6720 & 12.53 & 12.00 & 9.10 \\
\hline Mean & 2.27 & 1.95 & 4.28 & 0.40 & 2050 & 1941 & 4045 & 7.87 & 10.43 & 7.06 \\
\hline St. Dev. & 1.10 & 1.74 & 1.53 & 0.31 & 808 & 1686 & 1483 & 2.04 & 1.20 & 0.99 \\
\hline
\end{tabular}


To examine the effects of HCI by species and the effect of total HCI and total density on spruce PBAI, response surface analyses were conducted using the central composite design type and reduced quadratic design mode in Stat-Ease Design Expert $^{\circ}$ Ver. 8.0.4 software. Both response and explanatory variables were continuous. To ensure that the assumptions of normality, homoscedasticity and linearity were met, the following diagnostic plots were observed:1) normal probability plot of the studentized residuals to check for normality of residuals, 2) studentized residuals versus predicted values to check for constant error, 3) externally studentized residuals to look for outliers (i.e., influential values) and 4) Box-Cox plot for power transformations. Based on these diagnostics, no transformations were required to improve the fit to normality.

Repeated measures ANOVA was done using SPSS (ver.17.0), followed by Duncan's post hoc test, to determine the onset of nutrient stability in current foliage by mixture and to test for differences between mixtures after stability was reached. Shapiro Wilk's test for normality and Levene's test of homogeneity of variance of residuals were performed for each nutrient model. Residuals were normally distributed with homogenous variance.

To explore the relationships between white spruce growth (PBAI) and foliar nutrient levels with stand (i.e., HCIs), soil physical and chemical properties, and water-holding capacity, correlation analysis was performed using PROC CORR in SAS, ver. 9.1. The correlation analysis used foliar nutrient concentration data from one-yearold foliage collected after the point of stability (i.e., late August) as it has been shown that foliage formed in the previous year tends to be more stable/reliable as an index of soil nutrient availability (Powers 1984).

Following the correlation analysis, a multiple linear regression (MLR, backward elimination) was performed to examine, and partition, the influence of aboveground (e.g., competition levels) and belowground (e.g., nutrients and water) resources on the dependent variable of interest, white spruce growth (PBAI). Using the results from the correlation analysis, the number of independent variables in the MLR was reduced using $P<0.05$ as the selection criteria. Of the original 33 independent variables (8 - aboveground; 21 - soil nutrient; 3 - soil moisture), 12 variables ( 4 - aboveground ; 5 - soil nutrient; 3 soil moisture) were used in the MLR analysis.

\section{Results}

Individual tree growth response

Based on the linear regression results, spruce PBAI $\left(\mathrm{cm}^{2}\right.$ per year $)$ declined significantly $(P=$ 0.001 ) as total tree competition (HCI) increased (Fig. 1). The model suggests a linear decline of approximately $10 \%$ in spruce PBAI for each additional unit of total tree $\mathrm{HCI}$ within the range of competition (HCI: 2 to 8 ) in this study. There was not, however, any significant difference in the competition-induced growth decline whether the competition was dominated by aspen versus spruce (i.e., slopes were not significantly different, $P=0.54$ ). This was confirmed in the response surface analysis (Fig. 2), where a linear response surface was defined by the model that fit spruce PBAI response to both spruce HCI and aspen HCI. Both spruce HCI and aspen HCI were significant model terms $(P<0.03)$, but a unit increase in spruce HCI

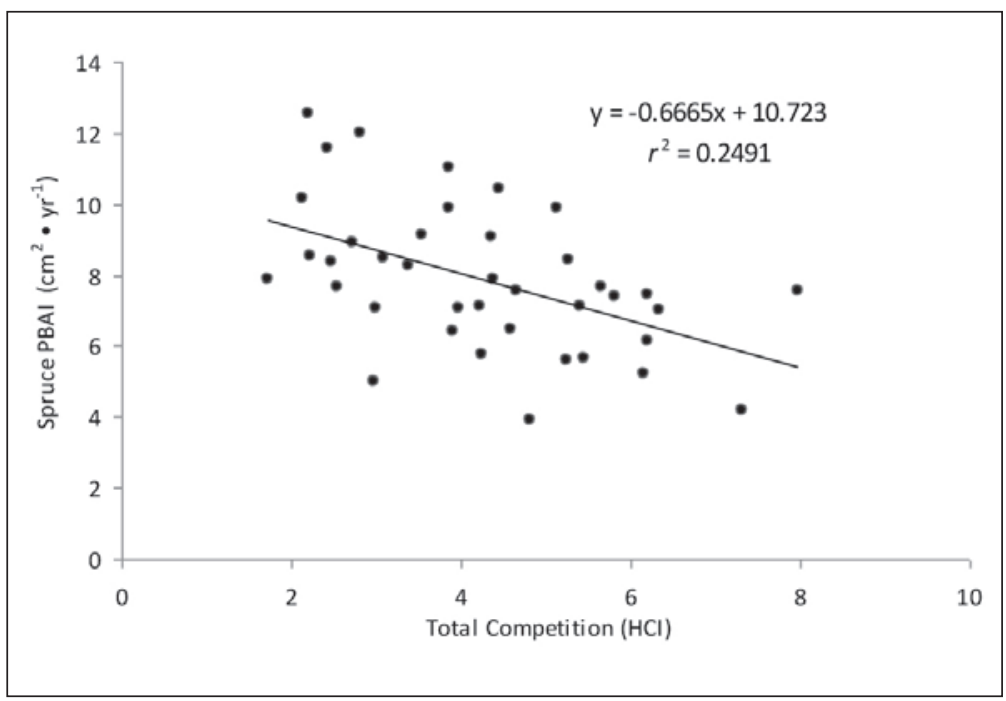

Fig. 1. Effect of total competition (Hegyi's Competition Index - HCl) on Periodic Basal Area Increment (PBAl) for 39 white spruce (19 to 22 years old) at the Fallingsnow Ecosystem Project.

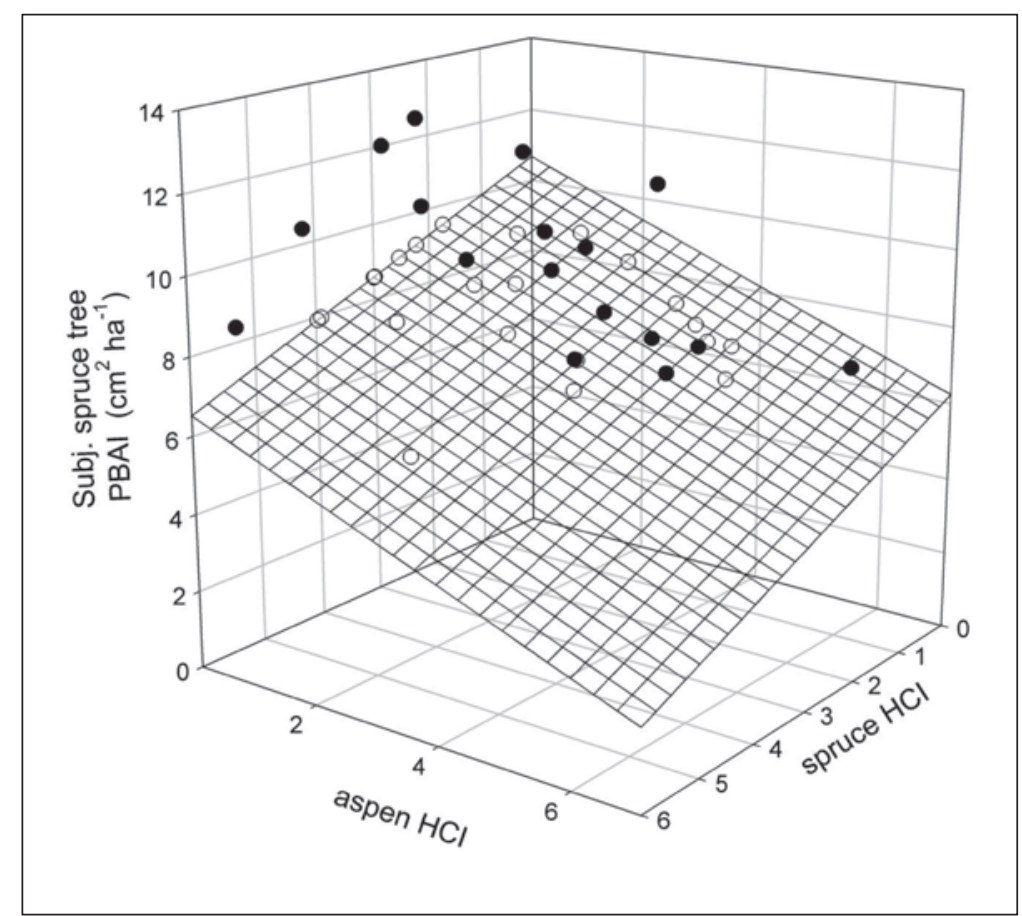

Fig. 2. The response of Periodic Basal Area Increment (PBAl) of 39 white spruce subject trees as affected by the amount of white spruce (spruce $\mathrm{HCl}$ ) and the amount of trembling aspen (aspen $\mathrm{HCl}$ ) competition in each TreeCentred Plot. Data points above the response surface are black, those below are white. The response surface model was: spruce PBAl $=10.68426$ (0.69335 x spruce $\mathrm{HCl})-(0.63559$ x aspen $\mathrm{HCl})$. 
resulted in only a slightly larger average reduction in spruce PBAI $(0.69 \mathrm{~cm}$ per year) than did a unit increase in aspen $\mathrm{HCI}$ $(0.64 \mathrm{~cm}$ per year). Although the overall model was significant $(P=0.007)$, it generated a low $r^{2}$ value $(0.24)$ suggesting that factors other than above-ground competition (HCI) also influence individual spruce growth.

\section{Spruce foliar nutrient status}

For the subset of 12 subject trees sampled repeatedly throughout the growing season, concentrations for all nutrients, with the exception of $\mathrm{Mg}$, changed significantly during the early portion of the measurement period (Table 2). Beginning in late May, and continuing through mid-July (four to six weeks following bud break), declining levels of $\mathrm{N}$ (1.75\% to $1.16 \%)$, $\mathrm{P}(0.27 \%$ to $0.19 \%)$, and $\mathrm{K}(1.03 \%$ to $0.75 \%)$ and increasing levels of $\mathrm{Ca}(0.21 \%$ to $0.53 \%)$ were detected. Although some differences in the timing of nutrient concentration stability did occur depending on the nutrient or species mixture (e.g., midJune for $\mathrm{P}$ and $\mathrm{K}$ in the aspen 25 mixture to late July for $\mathrm{Ca}$ in aspen0), levels of all nutrients measured were stable from the end of July through to mid-October.

When examining the foliar nutrient concentration data after stability was achieved (bolded values in Table 2), species mixture did have a significant influence on spruce foliar nutrient levels. For N (1.17\% to $1.31 \%, P=0.002), \mathrm{P}(0.15 \%$ to $0.23 \%, P<.001)$, and $\mathrm{K}(0.68 \%$ to $0.88 \%, P<0.001)$ increasing aspen presence resulted in significantly higher concentrations; whereas a pronounced decline in Ca levels $(0.81 \%$ to $0.48 \%, P<0.001)$ occurred as aspen presence increased. Although $\mathrm{Mg}$ concentrations were also significantly higher $(P=0.002)$ with aspen present, the differences were far more subtle $(0.08 \%$ to $0.10 \%)$ than for the other nutrients, unlikely to have been affecting plant function (i.e., $\mathrm{Mg}$ is a constituent of the chlorophyll molecule and is involved in several enzyme systems; Kramer and Kozlowski 1979).

\section{Linking spruce growth and foliar nutrient levels to competition and soil/site factors}

The results of the correlation analysis are summarized in Table 3 . Of the 31 competition (6), soil physical (2) and chemical (20), and water holding capacity (3) variables, spruce PBAI was significantly $(P<0.05)$ correlated with 10 variables. Both total HCI $(r=-0.545, P=0.011)$ and aspen HCI $(r=-0.470$, $P=0.032)$ were negatively correlated with spruce PBAI. In contrast, mineral soil fine fraction bulk density was positively related to spruce PBAI ( $r=0.654, P=0.001)$, with better growth occurring when bulk density was greater than $0.8 \mathrm{~g} \cdot \mathrm{cm}^{-3}$ (Fig. 3 ). Somewhat surprising, spruce PBAI was negatively correlated with soil chemical and water holding capacity parameters ( $r$ values $>-0.51, p$ values $<0.03)$. For example, poorer growth

Table 2. Results of the rmANOVA for the repeated spruce foliar sampling depicting the point of stability and the differences in nutrient concentrations between species mixture categories after stability was reached

\begin{tabular}{|c|c|c|c|c|c|c|c|c|c|}
\hline \multirow[b]{2}{*}{$\begin{array}{l}\text { Species } \\
\text { mixture }\end{array}$} & \multicolumn{8}{|c|}{ Date of sample (Julian day) } & \multirow[b]{2}{*}{$\begin{array}{l}\text { Mean at } \\
\text { stability }\end{array}$} \\
\hline & $\begin{array}{c}\text { May } 31 \\
(151)\end{array}$ & $\begin{array}{c}\text { Jun } 14 \\
(165)\end{array}$ & $\begin{array}{c}\text { Jun } 28 \\
(179)\end{array}$ & $\begin{array}{l}\text { Jul } 12 \\
(193)\end{array}$ & $\begin{array}{l}\text { Jul } 26 \\
(207)\end{array}$ & $\begin{array}{c}\operatorname{Aug} 23 \\
(235)\end{array}$ & $\begin{array}{c}\text { Sept } 20 \\
(263)\end{array}$ & $\begin{array}{c}\text { Oct } 18 \\
(291)\end{array}$ & \\
\hline \multicolumn{10}{|c|}{ Foliar N (\%) } \\
\hline aspen 0 & $1.72 \mathrm{a}$ & $1.36 \mathrm{~b}$ & $1.18 \mathrm{c}$ & $1.06 \mathrm{c}$ & $1.11 b c$ & $1.16 \mathrm{~b}$ & $1.26 \mathrm{~b}$ & $1.26 \mathrm{~b}$ & $1.17 \mathrm{~B}$ \\
\hline aspen 25 & $1.70 \mathrm{a}$ & $1.27 \mathrm{~b}$ & $1.18 \mathrm{~b}$ & $1.20 \mathrm{~b}$ & $1.24 \mathrm{~b}$ & $1.17 \mathrm{~b}$ & $1.21 b$ & $1.21 \mathrm{~b}$ & $1.21 \mathrm{~B}$ \\
\hline aspen50 & $1.84 \mathrm{a}$ & $1.50 \mathrm{~b}$ & $1.25 \mathrm{c}$ & $1.15 \mathrm{c}$ & $1.16 \mathrm{c}$ & $1.14 \mathrm{c}$ & $1.25 \mathrm{c}$ & $1.15 \mathrm{c}$ & $1.18 \mathrm{~B}$ \\
\hline aspen75 & $1.73 \mathrm{a}$ & $1.56 \mathrm{~b}$ & $1.35 \mathrm{c}$ & $1.24 \mathrm{c}$ & $1.23 \mathrm{c}$ & $1.34 \mathrm{c}$ & $1.35 \mathrm{c}$ & $1.37 \mathrm{c}$ & $1.31 \mathrm{~A}$ \\
\hline \multicolumn{10}{|c|}{ Foliar P (\%) } \\
\hline aspen 25 & $0.28 \mathrm{a}$ & $0.21 b$ & $0.19 b$ & $0.20 \mathrm{~b}$ & $0.20 \mathrm{~b}$ & $0.18 b$ & $0.18 b$ & $0.19 b$ & $0.19 \mathrm{~B}$ \\
\hline aspen50 & $0.27 \mathrm{a}$ & $0.23 \mathrm{ab}$ & $0.19 b c$ & $0.21 b c$ & $0.19 b c$ & $0.18 \mathrm{c}$ & $0.19 c$ & $0.19 b c$ & $0.19 \mathrm{~B}$ \\
\hline aspen75 & $0.28 \mathrm{a}$ & $0.27 \mathrm{ab}$ & $0.22 \mathrm{c}$ & $0.22 b c$ & $0.23 b c$ & $0.26 \mathrm{abc}$ & $0.23 b c$ & $0.24 \mathrm{abc}$ & $0.23 \mathrm{~A}$ \\
\hline $\begin{array}{l}\text { Foliar } K( \\
\text { aspen } 0\end{array}$ & $1.05 \mathrm{a}$ & $0.84 \mathrm{~b}$ & $0.68 b c$ & $0.70 b c$ & $0.65 c$ & $0.67 b c$ & $0.73 b c$ & $0.70 b c$ & $0.68 \mathrm{~B}$ \\
\hline aspen 25 & $1.00 \mathrm{a}$ & $0.72 b$ & $0.67 b$ & $0.70 b$ & $0.68 b$ & $0.67 b$ & $0.73 b$ & $0.73 b$ & $0.69 \mathrm{~B}$ \\
\hline aspen 50 & $1.02 \mathrm{a}$ & $0.99 \mathrm{ab}$ & $0.83 \mathrm{~cd}$ & $0.93 \mathrm{bc}$ & $0.87 \mathrm{~cd}$ & $0.81 d$ & $0.82 d$ & $0.85 \mathrm{~cd}$ & $0.85 \mathrm{~A}$ \\
\hline aspen75 & $1.04 \mathrm{a}$ & $0.99 a$ & $0.83 b$ & $0.92 a b$ & $0.91 \mathrm{ab}$ & $0.90 \mathrm{ab}$ & $0.93 a b$ & $0.83 b$ & $0.88 \mathrm{~A}$ \\
\hline \multicolumn{10}{|c|}{ Foliar Ca (\%) } \\
\hline aspen 0 & $0.23 \mathrm{~d}$ & $0.30 \mathrm{~d}$ & $0.37 \mathrm{~cd}$ & $0.58 \mathrm{bc}$ & $0.82 \mathrm{ab}$ & $0.73 \mathrm{ab}$ & $0.80 \mathrm{ab}$ & $0.89 a$ & $0.81 \mathrm{~A}$ \\
\hline aspen 25 & $0.19 c$ & $0.28 c$ & $0.37 \mathrm{bc}$ & $0.56 a b$ & $0.60 \mathrm{a}$ & $0.66 a$ & $0.66 a$ & $0.71 \mathrm{a}$ & $0.64 \mathrm{~B}$ \\
\hline aspen50 & $0.21 \mathrm{~d}$ & $0.26 \mathrm{~cd}$ & $0.45 b c$ & $0.49 \mathrm{ab}$ & $0.60 \mathrm{ab}$ & $0.68 a$ & $0.69 a$ & $0.61 \mathrm{ab}$ & $0.59 \mathrm{BC}$ \\
\hline aspen75 & $0.19 \mathrm{~d}$ & $0.25 \mathrm{~d}$ & $0.38 \mathrm{c}$ & $0.47 \mathrm{abc}$ & $0.51 \mathrm{ab}$ & $0.41 b c$ & $0.48 \mathrm{abc}$ & $0.55 a$ & $0.48 \mathrm{C}$ \\
\hline \multicolumn{10}{|c|}{ Foliar Mg (\%) } \\
\hline aspen 0 & $0.10 \mathrm{ab}$ & $0.08 \mathrm{~b}$ & $0.08 \mathrm{~b}$ & $0.09 b$ & $0.08 \mathrm{~b}$ & $0.08 \mathrm{~b}$ & $0.09 \mathrm{ab}$ & $0.11 \mathrm{a}$ & $0.08 \mathrm{~B}$ \\
\hline aspen 25 & $0.09 \mathrm{abc}$ & $0.08 \mathrm{c}$ & $0.08 \mathrm{bc}$ & $0.10 \mathrm{ab}$ & $0.09 \mathrm{abc}$ & $0.09 \mathrm{abc}$ & $0.09 \mathrm{abc}$ & $0.11 \mathrm{a}$ & $0.09 \mathrm{~A}$ \\
\hline aspen 50 & $0.10 \mathrm{ab}$ & $0.09 \mathrm{~b}$ & $0.10 \mathrm{ab}$ & $0.11 \mathrm{a}$ & $0.10 \mathrm{ab}$ & $0.10 \mathrm{ab}$ & $0.11 \mathrm{a}$ & $0.11 \mathrm{a}$ & $0.10 \mathrm{~A}$ \\
\hline aspen75 & $0.09 \mathrm{~b}$ & $0.07 \mathrm{~b}$ & $0.09 \mathrm{bc}$ & $0.10 \mathrm{ab}$ & $0.10 \mathrm{ab}$ & $0.10 \mathrm{ab}$ & $0.11 \mathrm{ab}$ & $0.12 \mathrm{a}$ & $0.10 \mathrm{~A}$ \\
\hline
\end{tabular}

a based on post hoc tests; dates of onset of stability varied from mid-June (e.g., aspen $25 \mathrm{P}$ or K) to late July (e.g., aspen0 Ca); majority were stable by mid-July. Bold values indicate those periods where data was used to determine foliar concentration at stability. 
Table 3. Summary of significant $(P<.05)$ Pearson correlation coefficients $(r)$ examining the relationships between spruce growth (PBAl) with stand (competition indices), soil physical and chemical attributes, and soil water holding capacity and their interrelationships.

\begin{tabular}{|c|c|c|c|c|c|c|c|c|c|c|c|}
\hline & PBAI & $\begin{array}{l}\text { total } \\
\text { HCI }\end{array}$ & $\begin{array}{c}\text { aspen } \\
\text { HCI }\end{array}$ & $\min B D$ & $\min p H$ & $\operatorname{minTC}$ & $\min T N$ & $\operatorname{minTSN}$ & mcfield & mcpwp & mcdiff \\
\hline \multirow[t]{2}{*}{ PBAI } & 1.000 & -.545 & -.470 & .654 & -.515 & -.621 & -.517 & -.623 & -.556 & -.559 & -.517 \\
\hline & - & $(.011)$ & $(.032)$ & $(.001)$ & $(.017)$ & $(.005)$ & $(.023)$ & $(.004)$ & $(.017)$ & $(.016)$ & $(.028)$ \\
\hline \multirow[t]{2}{*}{ total HCI } & - & 1.000 & .783 & -.639 & .607 & .390 & .255 & .193 & .339 & .258 & .368 \\
\hline & - & - & $(<.001)$ & $(.002)$ & $(.004)$ & $(.100)$ & $(.292)$ & $(.429)$ & $(.169)$ & $(.301)$ & $(.133)$ \\
\hline \multirow[t]{2}{*}{ aspenHCI } & - & - & 1.000 & -.471 & .362 & .128 & -.046 & .016 & .064 & .092 & .041 \\
\hline & - & - & - & $(.031)$ & $(.107)$ & $(.601)$ & $(.852)$ & $(.947)$ & $(.802)$ & $(.716)$ & $(.873)$ \\
\hline \multirow[t]{2}{*}{$\min B D$} & - & - & - & 1.000 & -.861 & -.739 & -.678 & .585 & -.652 & -.688 & -.585 \\
\hline & - & - & - & - & $(<.001)$ & $(<.001)$ & $(.001)$ & $(.009)$ & $(.003)$ & $(.002)$ & $(.001)$ \\
\hline \multirow[t]{2}{*}{$\operatorname{minpH}$} & - & - & - & - & 1.000 & .897 & .851 & .717 & .873 & .857 & .825 \\
\hline & - & - & - & - & - & $(<.001)$ & $(<.001)$ & $(.001)$ & $(<.001)$ & $(<.001)$ & $(<.001)$ \\
\hline \multirow[t]{2}{*}{$\operatorname{minTC}$} & - & - & - & - & - & 1.000 & .919 & .858 & .948 & .872 & .934 \\
\hline & - & - & - & - & - & - & $(<.001)$ & $(<.001)$ & $(<.001)$ & $(<.001)$ & $(<.001)$ \\
\hline \multirow[t]{2}{*}{$\operatorname{minTN}$} & - & - & - & - & - & - & 1.000 & .859 & .968 & .949 & .915 \\
\hline & - & - & - & - & - & - & - & $(<.001)$ & $(<.001)$ & $(<.001)$ & $(<.001)$ \\
\hline \multirow[t]{2}{*}{$\operatorname{minTSN}$} & - & - & - & - & - & - & - & 1.000 & .847 & .762 & .845 \\
\hline & - & - & - & - & - & - & - & - & $(<.001)$ & $(.001)$ & $(<.001)$ \\
\hline \multirow[t]{2}{*}{ mcfield } & - & - & - & - & - & - & - & - & 1.000 & .938 & .974 \\
\hline & - & - & - & - & - & - & - & - & - & $(<.001)$ & $(<.001)$ \\
\hline \multirow[t]{2}{*}{ mсрwp } & - & - & - & - & - & - & - & - & - & 1.000 & .834 \\
\hline & - & - & - & - & - & - & - & - & - & - & $(<.001)$ \\
\hline mcdiff & - & - & - & - & - & - & - & - & - & - & 1.000 \\
\hline
\end{tabular}

Abbreviations: minBD - mineral soil fine fraction bulk density, minpH - mineral soil pH, minTC - mineral soil total carbon, minTN - mineral soil total nitrogen, minTSN - mineral soil total soluble nitrogen, mcfield - moisture content at field capacity, mcpwp - moisture content at permanent wilting point, mcdiff - the water content difference between field capacity and permanent wilting point, PBAI - Periodic Basal Area Increment ( $\mathrm{cm}^{2}$ per year).

appeared to occur when mineral soil total carbon was greater than $5 \%$ and the water content at permanent wilting point was greater than $10 \mathrm{~m}^{3} \cdot \mathrm{m}^{-3}$ (Fig. 3).

When the suite of independent variables were included in the multiple linear regression model (backward elimination procedure), the final MLR model $\left(r^{2}=0.836, P=0.0002\right)$ retained five variables in the model to best predict white spruce growth (PBAI); two associated with the above-ground influences (aspen HCI and spruce HCI) and three associated with below-ground factors (mineral soil C, mineral soil total soluble nitrogen, available soil moisture) (Table 4). Based on the partial $r^{2}$ values, mineral soil $\mathrm{C}$ was the strongest contributor to explaining white spruce growth response, followed by aspen HCI, and available soil moisture.

Additional correlation analyses were run to examine the relationship between spruce foliar concentrations and the soil nutrient variables. In these analyses, spruce foliar $\mathrm{N}, \mathrm{P}$, and $\mathrm{K}$ concentrations were significantly correlated to soil nutrient or $\mathrm{pH}$ levels. Foliar $\mathrm{N}$ was positively correlated to total $\mathrm{N}$ in both the organic $(r=0.482, P=0.032)$ and mineral $(r=0.460, P=$ $0.047)$ soil horizons. Similarly, foliar $P$ was correlated to available $\mathrm{P}$ (Bray's $\mathrm{P})$ in the organic $(r=0.479, P=0.033)$ and mineral soil $(r=0.603, P=0.006)$. In the case of foliar $\mathrm{K}$, higher levels were associated with higher $\mathrm{pH}$ values in both the organic $(r=0.471$, $P=0.031)$ and mineral $(r=0.593, P=0.005)$ soil horizons. The correlation analysis confirmed the previously reported analyses where an increased presence of aspen improved spruce foliar $\mathrm{N}$, $\mathrm{P}$, and $\mathrm{K}$ concentrations (Table 2; rmANOVA). Increasing aspen was significantly correlated to $\mathrm{pH}$ of the $\mathrm{O}$ horizon $(r=0.483$, $P=0.027$ ) but not to any of the other soil nutrient parameters, including estimates of available (inorganic) $\mathrm{N}(P>0.40)$.

\section{Discussion}

Although the possibility of a positive interaction between white spruce and trembling aspen has been suggested by several authors, evidence for or against this result at the individual tree level has been lacking until now. Total competition negatively affected spruce growth (Fig. 1), but our results suggest that there is no difference in the competitive effect based on species (Fig. 2 ). In other words, the competition associated with aspen and spruce over the range reported in our study is similar. It has been reported that out of trembling aspen, pin cherry (Prunus pensylvanica L. f.), paper birch (Betula papyrifera Marsh.) and balsam fir (Populus balsamifera L.), aspen was consistently a weaker competitor (Boivin et al. 2010). Furthermore, in mature stands (i.e., $>100$ years) bivariate analysis did not detect any spatial association, negative or positive, between aspen and spruce (Gray and He 2009). However, they note that because their analysis was based on mortality, reduced growth could be occurring due to competition.

While species composition of competing trees (aspen vs. spruce) did not appear to influence the growth of subject spruce trees, there does appear to be some level of influence on foliar nutrition of spruce from the presence of aspen. Foliar concentrations of $\mathrm{N}, \mathrm{P}$, and $\mathrm{K}$ were significantly higher when aspen was present in the TCPs, particularly in the aspen 75 category (Table 2). Aspen has been noted to have a greater ability to take up nutrients from the soil (Paré and Van Cleve 1993) resulting in high concentrations in the foliage, which, in turn, decompose more rapidly than those of white spruce (Van Cleve et al. 1983). The significantly lower level of $\mathrm{Ca}$ in the spruce foliage where aspen is present does, however, suggest that aspen may be a strong competitor for available soil Ca compared to spruce. The lack 
Table 4. Results of a Multiple Linear Regression (backward elimination) to explain white spruce growth (Periodic Basal Area Increment, $\mathrm{cm}^{2}$ per year]

\begin{tabular}{|c|c|c|c|c|c|}
\hline Parameter & Value & S.E. & F ratio & $P$-value & Partial $r^{2}$ \\
\hline Intercept & 15.40 & 4.84 & 10.12 & 0.008 & \\
\hline $\begin{array}{l}\text { Mineral soil } \\
\text { carbon }\end{array}$ & -0.52 & 0.17 & 9.03 & 0.011 & 0.386 \\
\hline Aspen HCI & -11.53 & 4.47 & 6.66 & 0.024 & 0.201 \\
\hline mcdiff $^{a}$ & -0.07 & 0.04 & 4.11 & 0.065 & 0.131 \\
\hline Spruce HCI & -8.92 & 4.48 & 3.97 & 0.070 & 0.050 \\
\hline $\begin{array}{l}\text { Mineral soil } \\
\text { total soluble N }\end{array}$ & -0.04 & 0.02 & 3.64 & 0.080 & 0.049 \\
\hline Final Model & & & & 0.0002 & 0.8363 \\
\hline
\end{tabular}

${ }^{a}$ mcdiff - available soil moisture (water content difference between field capacity and

of realized spruce growth response to increased foliar nutrient levels is likely, in part, because, with the exception of N, nutrient levels across all species mixture categories were equal to or greater than defined critical levels (Ballard and Carter 1986). In the case of $\mathrm{N}$, foliar $\mathrm{N}$ levels were below the recommended critical levels (1.55\%) for all species mixtures (Table 2). These critical levels, however, were derived from nursery-grown (26 weeks) white spruce seedlings, and not for established, plantation-grown white spruce.

The original vegetation management treatments conducted at the FEP, applied 17 years prior to this study, reduced the amount of aspen on site to various degrees but did not directly influence soil nutrient levels (Simpson et al. 1997). Given that macro-climate and edaphic factors have not changed, the biggest influence on nutrient dynamics in the rooting horizon would come from the vegetation. Specifically, the variation in aspen presence was expected to affect the amount and type of light, litterfall and net precipitation reaching the forest floor leading to changes in microclimate, understory vegetation and biological activity. Observation confirms changes in understory vegetation cover and richness especially between pure spruce and mixedwood plots (F.W. Bell, Research Scientist, Ontario Forest Research Institute, OMNR, unpublished data, September 2013) but, with the exception of the soil $\mathrm{O}$ horizon $\mathrm{pH}$, increasing presence of aspen was not correlated to the suite of soil chemical parameters examined in this study (Table 3 and additional correlation analyses). These results are consistent with Binkley's review (1995), in which he states that there is no strong evidence to suggest hardwoods improve soil nutrient levels, with the exception of some nitrogen-fixing species.

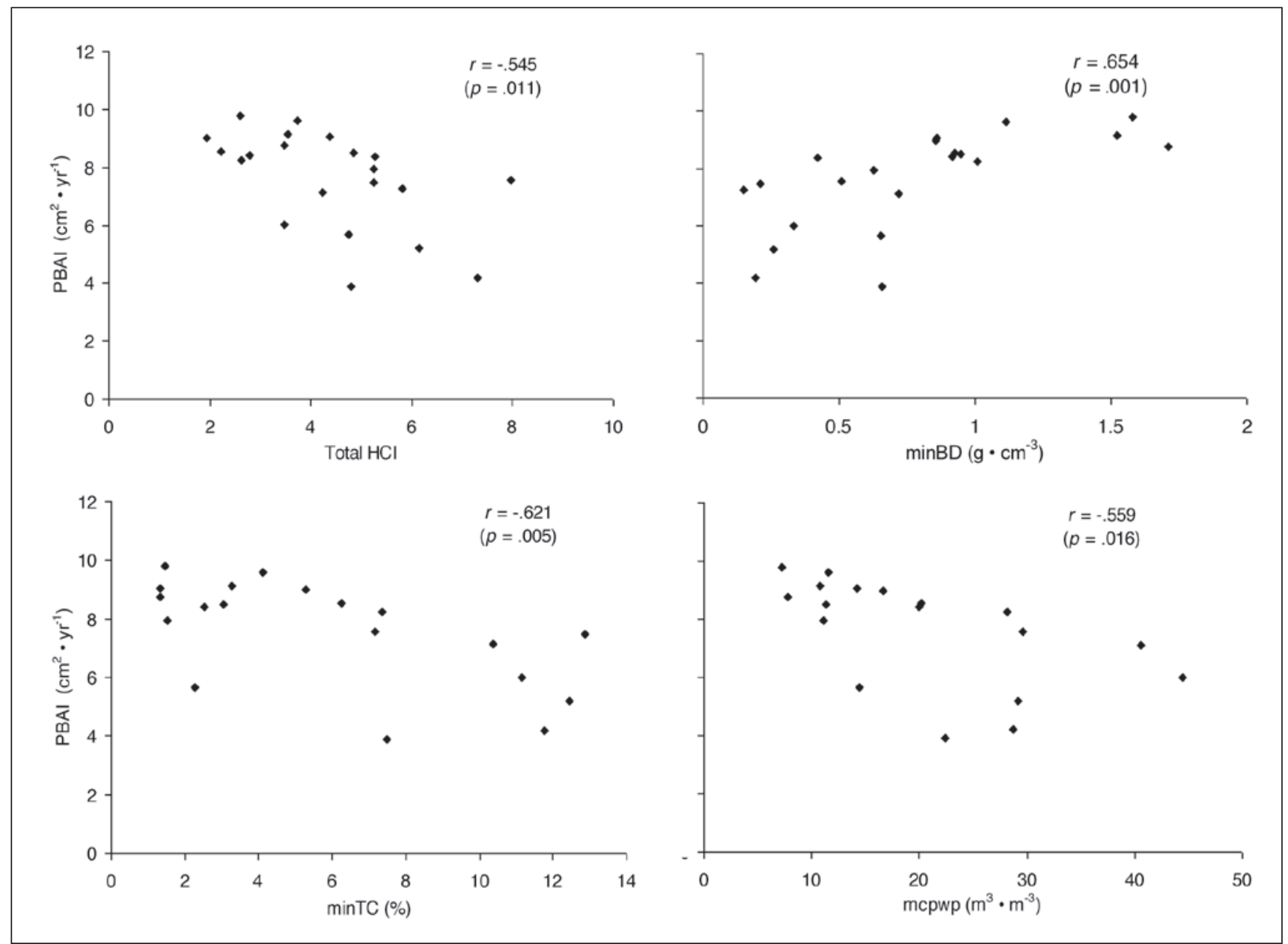

Fig. 3. Scatter plots depicting the relationship between spruce growth (PBAl) with total $\mathrm{HCl}$, mineral soil fine fraction bulk density (minBD), mineral soil total carbon (minTC), and moisture content at permanent wilting point (mcpwp). 
Low $r^{2}$ in the relationship between HCI and spruce PBAI suggests that other factors, such as species-specific competitive mechanisms or site, may have also influenced growth across the range of competition experienced by the subject trees. Filipescu and Comeau (2007) reported that competition alone explained $<60 \%$ of the variation in spruce stem growth 10 to 12 years after planting and suggested that aspen competition was only one of many factors affecting growth (Green 2004). As these trees are older, and have entered the stem exclusion phase of stand development it is not surprising that competition as we measured it has had a lesser influence on growth than have other site factors. The subject trees in our study have all overcome competition from grass and shrubs, and so the sources of above-ground competition are now different than they would be for small seedlings. The constraints on early stand development have thus changed, and other factors are becoming increasingly important. The final model obtained using MLR indicates that while competition is still a contributing factor, the combination of soil carbon and available moisture (partial $\left.r^{2}=0.517\right)$ account for more than twice the variation of the combined effects of aspen and spruce competition (partial $r^{2}$ $=0.251$ ) (Table 4). It was surprising, however, that the slopes were negative. Mineral soil $\mathrm{N}$ levels were also negatively correlated (minTN: $r=-0.517, P=0.023$; minTSN: $r=-0.623, P$ $=0.004$ ) with spruce PBAI (Table 3 ). The soils at the FEP site have thick, well-developed Ah horizons with some sampling locations having high accumulations of soil organic matter (SOM). Although speculative at this stage, these high values (total carbon $>10 \%$ ), may be indicative of slow turnover rates of SOM and poor aeration (i.e., mottles present in the upper $50 \mathrm{~cm}$ of the soil profile) during portions of the growing season resulting in the slower growth rates of spruce trees planted at these locations. Although mineral soil bulk density was not retained in the final model, spruce PBAI was positively correlated with bulk density (Table 3), which also seems counter-intuitive. Others have, however, also reported similar positive responses in tree growth to increases in bulk density in controlled soil compaction experiments, particularly when initial bulk density is low as is the case in our study (Fleming et al. 2006). Growth response to soil compaction, however, is highly variable (i.e., can be positive, negative, or neutral) and is dependent on tree species, soil conditions at the time of compaction, and the resulting level of soil compaction (PageDumroese et al. 2006).

It is well known that white spruce survival and growth during the stand establishment phase can be significantly affected by competing vegetation (Morris and MacDonald 1991). As such, herbicides that target grasses, herbs, shrubs, and hardwoods are commonly applied within the first five years after planting (Morris and Forslund 1991, Pitt et al. 2010). By year 20, however, the plantation is entering the stem exclusion stage of stand development. At this stage, our results clearly show that high densities and competition levels had significant effects on white spruce growth in these plantations regardless of the species composition (i.e., aspen and spruce had similar competitive effects on spruce growth). The presence of aspen, however, also resulted in higher levels of $\mathrm{N}, \mathrm{P}$, and $\mathrm{K}$ in the spruce foliage (Table 2). These combined results suggest that precommercial thinning operations should focus on density control and inter-tree spacing, but also retain a reasonable amount of aspen resulting in well-spaced, free-growing (e.g., a target of total HCI of 2 to 4 ) mixed stands of white spruce and aspen.

\section{Conclusions}

This study utilized a 20-year-old experimental white spruce plantation, currently in the stem exclusion phase of stand development. At this stage of stand development, total competition negatively affected spruce growth, but there was no differential competitive effect from aspen versus spruce. Results from the multiple linear regression indicated that while competition was still a contributing factor, soil carbon and available moisture combined accounted for more than twice the variation in spruce growth than did competition factors alone. The presence of aspen, however, significantly increased soil $\mathrm{O}$ horizon $\mathrm{pH}$, and spruce foliar levels of $\mathrm{N}, \mathrm{P}$, and $\mathrm{K}$, but reduced $\mathrm{Ca}$ levels. These results suggest that precommercial thinning operations should focus on density control and inter-tree spacing, but also retain a reasonable amount of aspen resulting in well-spaced, free-growing (e.g., a target of total HCI of 4 or less) mixed stands of white spruce and aspen.

\section{Acknowledgements}

This work was funded through an NSERC Strategic Project Grant (\#STPGP350778-07) and completed with the help of students from the Faculty of Natural Resources Management, Lakehead University, Thunder Bay. The authors greatly appreciate the thorough and extremely helpful suggestions provided by the Associate Editor and two anonymous reviewers.

\section{References}

Ballard T.M. and R.E. Carter 1986. Evaluating forest stand nutrient status. British Columbia Min. For. Land Management Report No. 20.

Bell, F.W., J. Dacosta, M. Penner, A. Morneault, A. Stinson, B. Towill, N.J. Luckai and J. Winters. 2011. Longer-term volume trade-offs in spruce and jack pine plantations following various conifer release treatments. For. Chron. 87(2): 235-250. doi:10.5558/tfc2011-011.

Bell, F.W., R.A. Lautenschlager, R.G. Wagner, D.G. Pitt, J.W. Hawkins and K.R. Ride. 1997. Motor-manual, mechanical, and herbicide release affect early successional vegetation in northwestern Ontario. For. Chron. 73(1): 61-68. doi:10.5558/tfc73061-1.

Bell, F.W. et al. 2000. Intensive forest management in Ontario: summary of a 1999 science workshop. Ont. Min. Nat. Resour., Sci. Develop. Transf. Ser. No. 003.

Binkley, D. 1995. The influence of tree species on forest soils: processes and patterns. In D.J. Mead and I.S. Cornforth (eds.). Proceedings of the trees and soil workshop. Feb. 28 - Mar. 2, 1994, Lincoln Univ., New Zealand. pp. 1-33. Lincoln Univ. Press, Special Pub. No. 10.

Boivin, F., A. Paquette, M.J. Papaik, N. Thiffault and C. Messier. 2010. Do position and species identify of neighbours matter in 8-15-year-old post harvest mesic stands in the boreal mixedwood? For. Ecol. Manage. 260(7): 1124-1131. doi:10.1016/j.foreco.2010.06.037.

Boivin, J.R., K.F. Salifu and V.R. Timmer. 2004. Late-season fertilization of Picea mariana seedlings: intensive loading and outplanting response on greenhouse bioassays. Ann. For. Sci. 61(8): 737-745. doi:10.1051/forest:2004073.

Bokalo, M., P.G. Comeau and S.J. Titus. 2007. Early development of tended mixtures of aspen and spruce in western Canadian boreal forests. For. Ecol. Manage. 242(2-3): 175-184. doi:10.1016/j. foreco.2007.01.038.

Bristow, M., J.K. Vanclay, L. Brooks and M. Hunt. 2006. Growth and species interactions of Eucalyptus pellita in a mixed and monoculture plantation in the humid tropics of Queensland. For. Ecol. Manage. 233(2-3): 285-294. doi:10.1016/j.foreco.2006.05.019.

Clark, J.S., M. Wolosin, M. Dietze, I. Ibanez, S. LaDeau, M. Welsh and B. Kloeppel. 2007. Tree growth inference and prediction from diameter censuses and ring widths. Ecol. Appl. 17(7): 1942-1953. doi:10.1890/06-1039.1. 
Clinton, B.D., K.J. Elliot and W.T. Swank. 1997. Response of planted eastern white pine (Pinus strobus L.) to mechanical release, competition, and drought in southern Appalachians. South. J. of Appl. For. 21: 19-23.

Coates, K.D and P.J. Burton. 1999. Growth of planted tree seedlings in response to ambient light levels in northwestern interior cedar-hemlock forests of British Columbia. Can. J. For. Res. 29(9): 1374-1382. doi:10.1139/x99-091.

Cole, D.M. 1977. Protecting and storing increment cores in plastic straws. USDA For. Serv., Res. Note Int-216.

Comeau, P.G. 1996. Why mixedwoods? In P.G. Comeau and K.D. Thomas (eds.). Silviculture of temperate and boreal broadleaf-conifer mixtures. pp. 1-5. British Columbia Min. For., Land Manage. Hdbk. No. 36.

Constabel, A.J. and V.J. Lieffers. 1996. Seasonal patterns of light transmission through boreal mixedwood canopies. Can. J. For. Res. 26(6): 1008-1014. doi:10.1139/x26-111.

Cortini, F., P.G. Comeau and M. Bokalo. 2012. Trembling aspen competition and climate effects on white spruce growth in boreal mixtures of western Canada. For. Ecol. Manage. 277: 67-73. doi:10.1016/j. foreco.2012.04.022.

Filipescu, C.N and P.G. Comeau. 2007. Aspen competition affects light and white spruce growth across several boreal sites in western Canada. Can. J. For. Res. 37(9): 1701-1713. doi:10.1139/X07-011.

Fleming, R.L. et al. 2006. Effects of organic matter removal, soil compaction, and vegetation control on 5-year seedling performance: a regional comparison of long-term soil productivity sites. Can. J. For. Res. 36(3): 529-550. doi:10.1139/x05-271.

Gradowski, T., D. Sidders, T. Keddy, V.J. Lieffers and S.M. Landhausser. 2008. Effects of overstory retention and site preparation on growth of planted white spruce seedlings in deciduous and coniferous dominated boreal plains mixedwoods. For. Ecol. Manage. 255(11): 3744 - 3749. doi:10.1016/j.foreco.2008.03.008.

Gray, L. and F. He. 2009. Spatial point-pattern analysis for detecting density-dependent competition in a boreal chronosequence of Alberta. For. Ecol. Manage. 259(1): 98-106. doi:10.1016/j.foreco.2009.09.048.

Green, D.S. 2004. Describing condition-specific determinants of competition in boreal and sub-boreal mixedwood stands. For. Chron. 80(6): 736-742. doi:10.5558/tfc80736-6.

Groot, A. and D.W. Carlson. 1996. Influence of shelter on night temperatures, frost damage, and bud break of white spruce seedlings. Can. J. For. Res. 26(9): 1531-1538. doi:10.1139/x26-172.

Hegyi, F. 1974. A simulation model for managing jack-pine stands. In J. Fries (ed.). Growth models for tree and stand simulation. pp. 74-90. Royal College of Forestry, Stockholm, Sweden.

Horneck, D.A. and R.O. Miller. 1998. Determination of total nitrogen in plant tissue. In Y.P. Kalra (ed.). Handbook of reference methods for plant analysis. pp. 75-84. CRC Press, Boca Raton, FL.

Kalra, Y.P. and D.G. Maynard. 1991. Methods manual for forest soil and plant analysis. For. Can., NW Reg., North. For. Cent., Edmonton, AB. Inf. Rep. NOR-X-319.

Kelty, M.J. 1992. Comparative productivity of monocultures and mixed-species stands. In M.J. Kelty, B.C. Larson, and C.D. Oliver (eds.). The ecology and silviculture of mixed-species forests. pp. 125-141. Kluwer Academic Publishers, the Netherlands.

Kelty, M.J. 2006. The role of species mixtures in plantation forestry. For. Ecol. Manage. 233(2-3): 195-204. doi:10.1016/j.foreco.2006.05.011.

Kramer, P.J. and T.T. Kozlowski. 1979. Physiology of woody plants. Academic Press, New York.

Lawrence, D.J., N. Luckai, W.L. Meyer, C. Shahi, A.J. Fazekas, P. Kesanakurti and S. Newmaster. 2012. Distribution of white spruce lateral fine roots as affected by the presence of trembling aspen: root mapping using simple sequence repeat DNA profiling. Can. J. For. Res. 42(8): 1566-1576. doi:10.1139/x2012-082.
Lieffers, V.J., K.J. Stadt and Z. Feng. 2007. Free-to-grow regeneration standards are poorly linked to growth of spruce in boreal mixedwoods. For. Chron. 83(6): 818-824. doi:10.5558/tfc83818-6.

Lieffers, V.J., K.J. Stadt and S. Navratil. 1996. Age structure and growth of understory white spruce under aspen. Can. J. For. Res. 26(6): 1002-1007. doi:10.1139/x26-110.

Lorimer, C.G. 1983. Test of age-independent competition indices for individual trees in natural hardwood stands. For. Ecol. Manage. 6(4): 343-360.

MacKinnon, W.E. and D.A. MacLean. 2003. The influence of forest and stand conditions on spruce budworm defoliation in New Brunswick, Canada. For. Sci. 49: 657-667.

MacPherson, D.M., V.J. Lieffers and P.V. Blenis. 2001. Productivity of aspen stands with and without a spruce understory in Alberta's boreal mixedwood forests. For. Chron.77(2): 351-356. doi:10.5558/ tfc77351-2.

Man, R. and K.J. Greenway. 2004. Meta-analysis of understory white spruce response to release from overstory aspen. For. Chron. 80(6): 694-704. doi:10.5558/tfc80694-6.

Man, R. and V.J. Lieffers. 1997. Seasonal photosynthetic responses to light and temperature in white spruce (Picea glauca) seedlings planted under an aspen (Populus tremuloides) canopy and in the open. Tree Physiol.17(7): 437-444. doi: 10.1093/treephys/17.7.437.

Man, R. and V.J. Lieffers. 1999. Are mixtures of aspen and white spruce more productive than single species stands? For. Chron. 75(3): 505-513. doi:10.5558/tfc75505-3.

McAlister, J.A. and V.R. Timmer. 1998. Nutrient enrichment of white spruce seedlings during nursery culture and initial plantation establishment. Tree Physiol.18(3): 195-202. doi: 10.1093/treephys/18.3.195.

McClain, K.M. 1981. Definition and distribution of the boreal mixedwood forest in Ontario. In R.D. Whitney and K.M. McClain (eds.). Boreal Mixedwood Symposium Proceedings, Sept. 16-18, 1980, Thunder Bay, ON. pp. 5-9. COJFRC Symp. Proc. O-P-9.

Miller, R.O. 1998. Nitric-perchloric acid wet digestion in an open vessel. In Y.P. Kalra (ed). Handbook of reference methods for plant analysis. pp. 57-62. CRC Press, Boca Raton, FL.

Morris, D.M. and R.R. Forslund. 1991. A field-oriented competition index for young jack pine plantations and a computerized decision tool for vegetation management. New Forests 52): 93-107. doi:10.1007/ BF00029301.

Morris, D.M. and G.B. MacDonald. 1991. Development of a competition index for young conifer plantation established on boreal mixedwood sites. For. Chron. 67(4): 403-410. doi:10.5558/tfc67403-4.

Morris, D.M., G.B. MacDonald and K.M. McClain. 1990. Evaluation of morphological attributes as response variables to perennial competition for 4-year-old black spruce and jack pine seedlings. Can. J. For. Res. 20(11): 1696-1703. doi:10.1139/x90-226.

Munter, R.C. and R.A. Grande. 1981. Plant analysis and soil extracts by ICP-atomic emission spectrometry. In R.M. Barnes (ed.). Developments in atomic plasma spectrochemical analysis. pp. 653-672. John Wiley and Sons Ltd, London, UK.

Nienstaedt, H. and J.C. Zasada. 1990. White spruce. In M.R. Burns and H.B. Honkala (eds.). Silvics of North America: Volume 1. Conifers. pp. 204-226. U.S. Dept. Agric., For. Serv. Agric. Handbook 654.

Page-Dumroese, D.S. et al. 2006. Soil property changes at the North American long-term soil productivity study sites: 1 and 5 years after compaction. Can. J. For. Res. 36(3): 551-564. doi:10.1139/x05-273.

Paré, D. and K. Van Cleve. 1993. Aboveground biomass production and nutrient accumulation on post-harvested white spruce sites in interior Alaska. Can. J. For. Res. 23(6): 1233-1239. doi:10.1139/x93-155. Perala, D.A. 1990. Quaking aspen. In R.M. Burns and B.H. Honkala (eds.). Silvics of North America: Volume 2. Hardwoods. pp. 555-569. U.S. Dept. Agric., For. Serv. Agric. Handbook 654. 
Pitt, D.G and F.W. Bell. 2005. Juvenile response to conifer release alternatives on aspen-white spruce boreal mixedwood sites. Part I: Stand structure and composition. For. Chron. 81(4): 538-547. doi:10.5558/ tfc81538-4.

Pitt, D.G., P.G. Comeau, W.C. Parker, D. MacIsaac, S. McPherson, M.K. Hoepting, A. Stinson and M. Mihajlovich. 2010. Early vegetation control for the regeneration of a single-cohort, intimate mixture of white spruce and trembling aspen on upland boreal sites. Can. J. For. Res. 40(3): 549-564. doi:10.1139/X10-012.

Powers, R.F. 1984. Estimating soil nitrogen availability through soil and foliar analysis. In E.L. Stone (ed.). Forest soils and treatment impacts. Proceedings of the Sixth North American Forest Soils Conference. June, 1983. Univ. of Tennessee, Knoxville, Tennessee. pp. 353-379.

Pritchard, J.M. and P.G. Comeau. 2004. Effects of opening size and stand characteristics on light transmittance and temperature under young trembling aspen stands. For. Ecol. Manage. 200(1-3): 119-128. doi:10.1016/j.foreco.2004.06.002.

Rowe, J.S. 1972. Forest regions of Canada. Dept. of the Environ., Ottawa, ON. Can. For. Serv. Pub. No. 1300.

SAS Institute Inc. 1987. SAS/STAT guide for personal computers, Ver 6. SAS Institute Inc, Cary, NC.
Simpson, J.A., A.M. Gordon, P.E. Reynolds, R.A. Lautenschlager, F.W. Bell, D. Gresch and D. Buckley. 1997. Influence of alternative conifer release treatments on soil nutrient movement. For. Chron. 73(1): 63-73. doi:10.5558/tfc73069-1.

Soil Classification Working Group. 1998. The Canadian system of soil classification. $3^{\text {rd }}$ Edition. Agric. and Agri-Food Can. Publ. 1646.

Van Cleve, K., L. Oliver, R. Schlentner, L.A. Viereck and C.T. Dryness. 1983. Productivity and nutrient cycling in taiga forest ecosystems. Can. J. For. Res. 13(5): 747-766. doi:10.1139/x83-105.

Voicu, M.F. and P.G. Comeau. 2006. Microclimatic and spruce growth gradients adjacent to young aspen stands. For. Ecol. Manage. 221(1-3): 13-26. doi:10.1016/j.foreco.2005.09.016.

Wagner, R.G. and S.R. Radosevich. 1998. Neighbourhood approach for quantifying interspecific competition in coastal Oregon forests. Ecol. Appl. 8(3): 779-794. doi:10.1890/1051-0761.

Wang, G.G. and K. Klinka. 1997. White spruce nutrient concentrations in relation to tree growth and soil nutrient amounts. For. Ecol. Manage. 98(1): 89-99.

Wang, J.R., A.L. Zhong, P. Comeau, M. Tsze and J.P. Kimmins. 1995. Aboveground biomass and nutrient accumulation in an age sequence of aspen (Populus tremuloides) stands in the boreal white and black spruce zone, British Columbia. For. Ecol. Manage. 78(1-3): 127-138.

Zar, J.H. 1999. Biostatistical analysis. $4^{\text {th }}$ Edition. Prentice-Hall Inc., Engelwood Cliffs, N.J. 